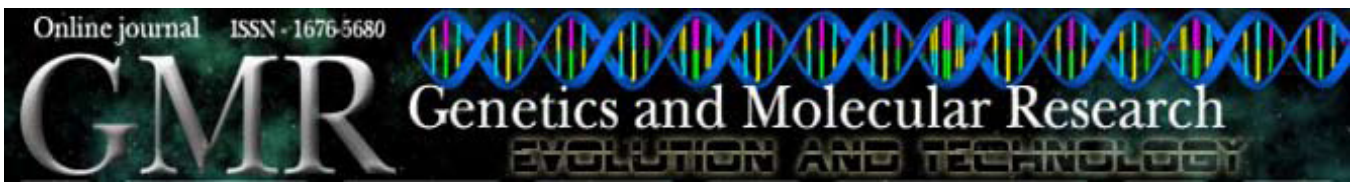

\title{
Isoenzyme electrophoretic patterns in discus fish (Symphysodon aequifasciatus Pellegrin, 1904 and Symphysodon discus Heckel, 1840) from the Central Amazon
}

\author{
C.A. Silva, R.C.A. Lima and A.S. Teixeira \\ Instituto Nacional de Pesquisas da Amazônia, Coordenação de Pesquisas em \\ Biologia Aquática, Manaus, AM, Brasil \\ Corresponding author: A.S. Teixeira \\ E-mail: saturn@inpa.gov.br
}

Genet. Mol. Res. 7 (3): 791-805 (2008)

Received February 29, 2008

Accepted March 22, 2008

Published September 9, 2008

\begin{abstract}
The discus is a very popular and expensive aquarium fish belonging to the family Cichlidae, genus Symphysodon, formed by three Amazon basin endemic species: Symphysodon aequifasciatus, S. discus and $S$. tarzoo. The taxonomic status of these fish is very controversial, with a paucity of molecular research on their population genetic structure and species identification. Information on molecular genetic markers, especially isoenzymes, in search of a better understanding of the population genetic structure and correct identification of fish species, has been receiving more attention when elaborating and implementing commercial fishery management programs. Aiming to contribute to a better understanding of the species taxonomic status, the present study describes the isoenzymatic patterns of 6 enzymes: esterase (Est - EC 3.1.1.1), lactate dehydrogenase (Ldh - EC 1.1.1.27), malate dehydrogenase (Mdh - EC 1.1.1.37), phosphoglucomutase (Pgm - EC 5.4.2.2), phosphoglucose isomerase (Pgi - EC 5.3.1.9), and super
\end{abstract}


oxide dismutase (Sod - EC 1.15.1.1) extracted from skeletal muscle specimens and analyzed by starch gel electrophoresis. Monomorphic patterns, presumably controlled by 11 loci: Est-1, Est-2, Est-3, Ldh-1, Ldh-2, Mdh-1, Mdh-2, Pgi-1, Pgi-2, Pgm-1, and Sod-1 were fixed for the same alleles: Est$1^{1}$, Est-2 ${ }^{1}$, Est- $3^{1}$, Ldh- ${ }^{1}$, Ldh-2 ${ }^{1}$, Mdh- $1^{1}$, Mdh- $2^{1}$, Pgi- $1^{1}$, Pgi- ${ }^{1}$, Pgm- $1^{1}$, and Sod- $1^{1}$, respectively, and detected in all 60 specimens examined (27S. aequifasciatus from Manacapuru and 33 S. discus from Novo Airão, Central Amazon). The failure in the present study to detect diagnostic loci, which could be very useful for differentiating $S$. aequifasciatus from $S$. discus species, and polymorphic loci, which could also be applied for possible identification and delimitation of their stocks, does not rule out the possibility of there existing in other isoenzyme gene loci to be analyzed in the future.

Key words: Discus fish; Central Amazon; Isoenzymes; Electrophoresis

\section{INTRODUCTION}

Since the 1950s, mainly after the discovery of the cardinal tetra (Paracheirodon axelrodi) in 1955 by Herbert R. Axelrod (Axelrod, 2001), the fisheries and commercialization of ornamental fish in the Amazon have been increasing more and more. In the State of Amazonas, ornamental fish, whose major fishing ground is the middle Negro River, are among the main exports, and are considered to be the third largest extractive product of the State (Chao and Prang, 2002). According to the Amazonas data bank of 2003 available at the Brazilian Institute of the Environment and Renewable Natural Resources (IBAMA), around 20 million ornamental fish are exported annually from this region, generating about US\$3 million for the local economy.

Considered as a renewable aquatic resource in the Amazon, ornamental fish show enormous potential as a sustainable model, especially in the Negro River tributaries (Chao, 2001). As the sustainable condition of this resource has recently been questioned (Gerstner et al., 2006), research about ecological fishery impact on ornamental fish populations should be urgently carried out and expanded in the region.

Having a variety of behaviors, attractive colors and moderate sizes, the cichlids are commonly used as ornamental fish (Kullander, 2003). Among these, the discus which belong to the order Perciformes, family Cichlidae, genus Symphysodon (Kullander, 1998) appear among the 180 species or varieties of freshwater fishes listed by IBAMA, which can be captured legally, commercialized and exported live from Brazil.

Discus fish are one of the most important fishery resources exploited in the Negro River basin (Chao, 2001).

The genus Symphysodon was previously considered as being formed by two species: Symphysodon aequifasciatus Pellegrin, 1904 and Symphysodon discus Heckel, 1840 (Kullander, 1996). However, Ready et al. (2006) based on color patterns, morphology and mitochondrial DNA (mtDNA) analyses of Symphysodon samples collected along the length of the Solimões-Amazon River, provided evidence for the existence of a third species, $S$. tarzoo Lyons, 1959, although at the mtDNA level they did not detect a difference between S. aequifasciatus and S. discus. On the other hand, Bleher et al. (2007) also con- 
ducted an mtDNA analysis of Symphysodon specimens collected from different locations in the Amazon basin, and revealed three genetically distinct clades, $S$. aequifasciatus, $S$. haraldi and S. discus.

The main point to be noted about the above data published by Ready et al. (2006) and Bleher et al. (2007) is that the green discus is named by Ready et al. (2006) as S. tar$z o o$, while Bleher et al. (2007) refer to it as $S$. aequifasciatus. The blue and brown discus are considered to be $S$. aequifasciatus by Ready et al. (2006), whereas, Bleher et al. (2007) treat them as $S$. haraldi.

The discus species are endemic to the Amazon basin with S. aequifasciatus showing an almost linear distribution from along the entire lowland course of the Amazon's mainstream, to the Tocantins River basin; $S$. discus with occurrence registered in the Negro River, lower Abacaxis River (tributary of the Madeira River) and lower Trombetas River (Kullander, 1996; Ready et al., 2006), and S. tarzoo can be found in the Içá, Juruá, Tefé, and Jutaí Rivers (western Amazon), with a slight overlap in distribution with $S$. aequifasciatus from the Madeira River downstream of the Purus arch (Ready et al., 2006). These fish are popularly known as discus due to their discoid shape (Axelrod et al., 1995). They are small in size; an average of $20 \mathrm{~cm}$ in the adult (Mills, 1998), and with the following general morphological characteristics: high-bodied, laterally compressed, with nine transversal dark bars on the sides (Silva and Kotlar, 1980; Axelrod et al., 1995; Ready et al., 2006). S. discus differentiates from the other two species, showing three of these transversal dark bars as much more prominent: the first one passing over the region of the eyes, the second over the middle region of the body, which is the widest and most intense, and the last on the caudal peduncle (Silva and Kotlar, 1980; Ready et al., 2006). The diagnostic phenotypic character of red spots on the anal fin and on the sides of the body distinguishes $S$. tarzoo from the other two Symphysodon species, which have reticulations (Ready et al., 2006). Although the morphometric characters traditionally used do not easily differentiate the genus species, the average lateral line scale counts and melanic pigmentation still can be used to differentiate $S$. discus and $S$. aequifasciatus, in which $S$. discus shows a greater variation in the number of longitudinal scales, smaller number of rays in the dorsal fin and smaller number of abdominal vertebrae in relation to $S$. aequifasciatus (Kullander, 1996).

As previously mentioned by Ready et al. (2006), research carried out on variation in fish color patterns has resulted in the descriptions of several subspecies in different geographic areas in the Amazon basin, namely, S. a. aequifasciatus, S. a. haraldi Schultz, 1960, S. a. axelrodi Schultz, 1960, and S. discus willischwartzi Burgess, 1981. Unfortunately, however, the descriptions of these subspecies are based only on a few samples of often uncertain origin (Ready et al., 2006).

The polemic on the taxonomic status of discus fish has persisted since the genus Symphysodon was first described by Heckel (1840) apud Koh et al. (1999). To this day, not only the validity of the existence of subspecies, but also the existence of the species formally described in this genus, have been frequently questioned (Mazeroll and Weiss, 1995; Koh et al., 1999).

Isoenzyme markers analyzed by means of electrophoresis have been applied quite often to solve taxonomic problems, especially where the morphological characteristics overlap or where there are variables within the genus or species (see Micales et al., 1998). 
When extracted from several biological tissues and analyzed electrophoretically, the isoenzymes have revealed enormous practicality for identifying species, hybrids, natural and cultured fish populations, and have been applied as an auxiliary tool for providing basic information for commercial fishery management policies (Smith and Robertson, 1981; Smith et al., 1981a,b; Jamieson and Smith, 1987; Utter, 1991; Guyomard, 1993; Carvalho and Hauser, 1994; Ferguson et al., 1995; Verspoor et al., 2005), with diagnostic loci (monomorphic loci with species-specific fixed alleles) having been applied for identifying species and polymorphic loci for identifying and delimiting fish stocks.

The present paper describes monomorphisms in the isoenzymatic electrophoretic patterns of the enzymes: esterase (Est), lactate dehydrogenase (Ldh), malate dehydrogenase (Mdh), phosphoglucomutase (Pgm), phosphoglucose isomerase (Pgi), and superoxide dismutase (Sod) extracted from the skeletal muscles of S. aequifasciatus and S. discus specimens from the Central Amazon. It also presents some literature research findings on chromosome and molecular markers applied to sort out the species taxonomic problems of discus fishes.

\section{MATERIAL AND METHODS}

\section{Sample collections}

After authorizations provided by the Brazilian Institute of Environment and Renewable Natural Resources (IBAMA) (Administrative Processes: \#02005.001766/04-11 and \#02005.001788//2005-26), 60 specimens of discus fish were taken from two areas in the Central Amazon, namely, 27 S. aequifasciatus ${ }^{1}$ from Manacapuru, Solimões River $\left(03^{\circ} 17^{\prime} \mathrm{S} 60^{\circ} 37^{\prime} \mathrm{W}\right)$ on November 23,2004 , and 33 S. discus from Novo Airão, Negro River ( $\left.02^{\circ} 37^{\prime} \mathrm{S} 60^{\circ} 56^{\prime} \mathrm{W}\right)$ on March 6, 2006 (Figures 1 and 2).

White skeletal muscle tissue specimens sampled from both species were stored in a

A

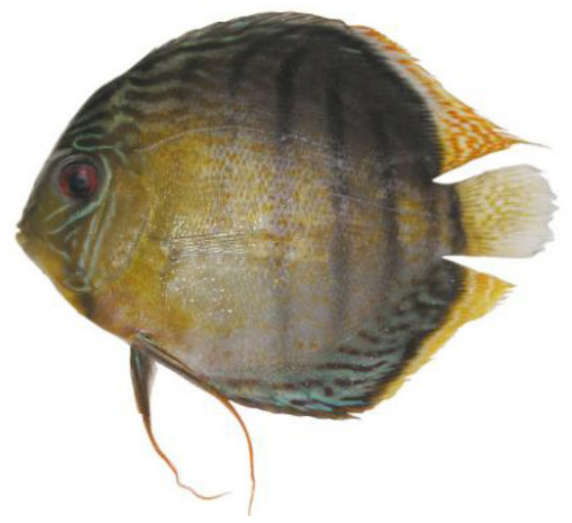

B

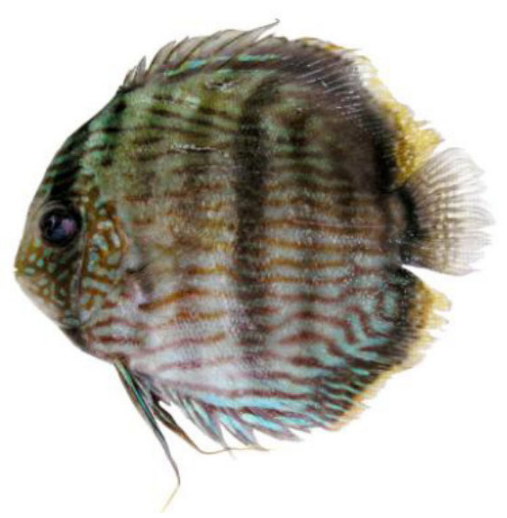

Figure 1. Discus fish species. A. Symphysodon aequifasciatus, $15.50 \mathrm{~cm}$ in total length and $105.60 \mathrm{~g}$ of weight. B. S. discus, $13.5 \mathrm{~cm}$ in total length and $75 \mathrm{~g}$ of weight.

${ }^{1}$ Symphysodon haraldi according to Bleher et al. (2007). 


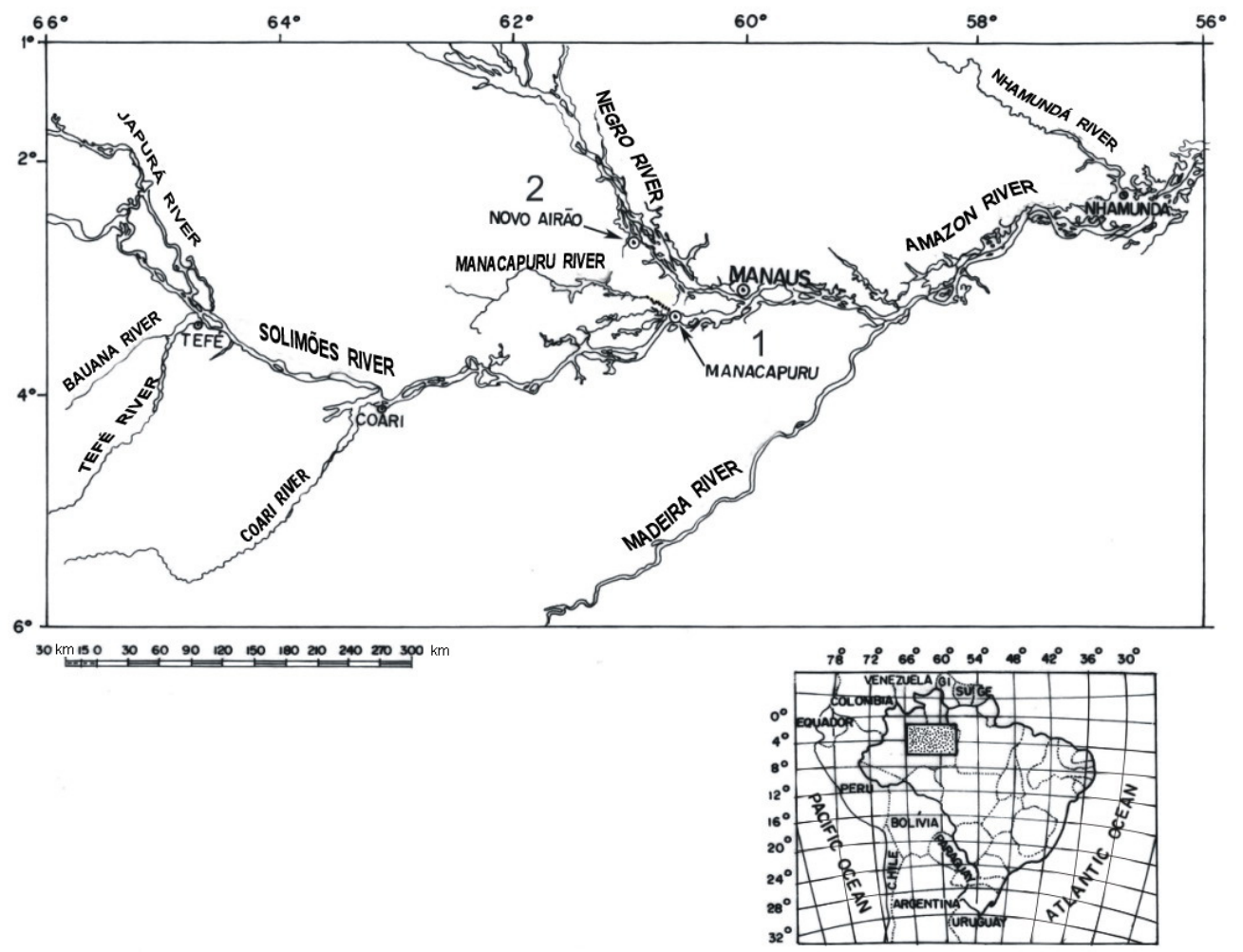

Figure 2. Sampling localities where the discus fish specimens were caught in the Central Amazon: Manacapuru (1) and Novo Airão (2).

freezer at $-25^{\circ} \mathrm{C}$, in the biological tissue bank of the Fish Genetics Laboratory at Coordination of Aquatic Biology Research (CPBA) - National Research Institute of Amazonia (INPA). The S. aequifasciatus muscle sample was collected and stored in a freezer from 2004 until electrophoretic analyses were performed in 2006, in contrast to the $S$. discus muscle sample, which was collected and stored in 2006 and immediately tested. After removing the tissue samples, the fish were labeled, initially fixed in 10\% formalin for 1 week and then in $70 \%$ alcohol, and deposited in the Fish Genetics Laboratory, CPBA/INPA. Voucher specimens were later sent to the collections of INPA (S. aequifasciatus: INPA 25497 and S. discus: INPA 26447).

\section{Preparation of protein extracts}

A day before electrophoretic analyses, the muscle samples were macerated manually with the aid of glass rods in 3-mL test tubes, in a proportion of one part muscle tissue to two parts $0.1 \mathrm{M}$ Tris- $\mathrm{HCl}$ buffer, $\mathrm{pH} 7.1$, containing $1 \% \beta$-mercaptoethanol and later stored in a freezer at $-25^{\circ} \mathrm{C}$ for approximately $18 \mathrm{~h}$. Moments before the electrophoretic runs, the samples were centrifuged at 3,000 rpm for $30 \mathrm{~min}$ in order to obtain the soluble protein supernatants. 


\section{Electrophoresis procedures}

The electrode buffer was $0.006 \mathrm{M}$ lithium hydroxide and $0.30 \mathrm{M}$ boric acid, whereas the gel buffer was prepared by adding $1 \mathrm{~mL}$ of the electrode buffer to every $100 \mathrm{~mL} 0.03 \mathrm{M}$ Tris (hydroxymethyl) aminomethane and $0.005 \mathrm{M}$ citric acid (Ridgway et al., 1970). Both buffers were adjusted to $\mathrm{pH} 8.20$ with $1 \mathrm{M}$ lithium hydroxide. Sigma starch gels at a concentration of $8.35 \%$ were made up in $340 \mathrm{~mL}$ of the gel buffer. By means of a continuous stirring process performed with a simple mechanical stirrer, starch mixed in buffer was heated up to $90^{\circ} \mathrm{C}$ in a 2-liter round-bottom flask supported by a heating mantle. The soluble protein supernatants were absorbed into $8 \times 5$-mm rectangular filter papers (Whatman $3 \mathrm{MM}$ ), which were then inserted on the gels. A potential of $150 \mathrm{~V}$ for each gel slab was applied for a period of 5 to $6 \mathrm{~h}$ with the electrophoretic migration occurring towards the anode.

\section{Nomenclature}

The enzymes surveyed in the present paper were classified according to the Nomenclature Committee of the International Union of Biochemistry and Molecular Biology (2006), where each enzyme name is written in full and enzyme abbreviation and EC code in parentheses, as follow: esterase (Est - EC 3.1.1.1), lactate dehydrogenase (Ldh - EC 1.1.1.27), malate dehydrogenase (Mdh - EC 1.1.1.37), phosphoglucomutase (Pgm - EC 5.4.2.2), phosphoglucose isomerase (Pgi - EC 5.3.1.9), and superoxide dismutase (Sod - EC 1.15.1.1).

The isoenzyme loci and alleles were identified and classified numerically according to their decreasing electrophoretic mobilities towards the anode.

\section{Enzyme staining}

The revelation of isoenzyme bands in the zymograms occurred on starch gels, which were immersed and incubated in staining solutions containing chemical components (substrates, coenzymes, electron carriers, buffer solutions, and tetrazolium salts) necessary to detect enzymatic activities as described below for each enzyme system tested.

\section{Esterase (Est - EC 3.1.1.1)}

The staining solution for detecting the enzyme esterase was prepared with $2.8 \mathrm{~mL} 1 \%$ $\alpha$-naphthyl acetate dissolved in acetone, $70 \mathrm{mg}$ fast blue RR salt, $70 \mathrm{~mL} 0.4 \mathrm{M}$ sodium phosphate monobasic monohydrate, pH 6.55 (Ridgway et al., 1970). The gel slices were placed in plastic trays, immersed in the above solution and later incubated at $37^{\circ} \mathrm{C}$ in a laboratory oven for approximately $30 \mathrm{~min}$ or until the development of the bands. The staining solution was then discarded and the gels, after being washed with distilled water, were fixed in a $10 \%$ glycerol solution of 5:5:1 parts of water, methanol and acetic acid, respectively.

\section{Lactate dehydrogenase (Ldh - EC 1.1.1.27)}

For detecting the enzyme lactate dehydrogenase, the staining solution used was prepared according to the method described by Alfenas et al. (1991) with modifications, where 14 
$\mathrm{mg} ß$-nicotinamide adenine dinucleotide (NAD), $2 \mathrm{mg}$ phenazine methosulfate (PMS), $14 \mathrm{mg}$ 3-[4,5-dimethylthiazol-2-yl]-2,5-diphenyl-tetrazolium bromide (MTT), and $7 \mathrm{~mL} \mathrm{85 \%} \mathrm{DL-}$ lactic acid were dissolved in $70 \mathrm{~mL} 0.5 \mathrm{M}$ sodium phosphate monobasic monohydrate buffer, $\mathrm{pH}$ 7.0. The gel slices were placed in plastic trays, soaked in the above solution and incubated in a laboratory oven at $37^{\circ} \mathrm{C}$ for 2 to $3 \mathrm{~h}$ until the color development of the bands.

\section{Malate dehydrogenase (Mdh - EC 1.1.1.37)}

The staining recipe for detecting the enzyme malate dehydrogenase was the one described by Allendorf et al. (1977) with modifications, where $5 \mathrm{mg}$ PMS, $10 \mathrm{mg}$ MTT, and $5 \mathrm{mg}$ NAD were mixed with $25 \mathrm{~mL} 0.5 \mathrm{M}$ DL-malic acid buffer, $\mathrm{pH}$ 8.0, and $0.1 \mathrm{M}$ Tris- $\mathrm{HCl}$ buffer, $\mathrm{pH}$ 8.5. The above solution was poured on the gel slices in plastic trays, which were then incubated in a laboratory oven at $37^{\circ} \mathrm{C}$ for about $2 \mathrm{~h}$ until the development of the bands. Finally, the staining solution was then discarded and the gels, after being washed with distilled water, were fixed in a 10\% glycerol solution and kept in a refrigerator for about $18 \mathrm{~h}$ for further typing.

\section{Phosphoglucomutase (Pgm - EC 5.4.2.2)}

The staining recipe for detecting the enzyme phosphoglucomutase followed the methods described by Alfenas et al. (1991) and Brune et al. (1998) with modifications, where 2.8 $\mathrm{mg}$ PMS, $14 \mathrm{mg}$ MTT, $14 \mathrm{mg}$ ß-nicotinamide adenine dinucleotide phosphate (NADP), $28 \mu \mathrm{L}$ glucose-6-phosphate dehydrogenase (G-6-PDH), $28 \mathrm{mg}$ magnesium chloride $\left(\mathrm{MgCl}_{2}\right)$, and $70 \mathrm{mg}$ glucose-1-phosphate were dissolved in $70 \mathrm{~mL} 0.2 \mathrm{M}$ Tris- $\mathrm{HCl}$ buffer, $\mathrm{pH}$ 8.0. The gel slices were then placed in plastic trays, immersed in the above solution and later incubated in a laboratory oven at $37^{\circ} \mathrm{C}$ for approximately $25 \mathrm{~min}$ until bands were revealed. The staining solution was then discarded and the gels, after being washed with distilled water, were fixed in a 10\% glycerol solution of 5:5:1 parts of water, methanol and acetic acid, respectively.

\section{Phosphoglucose isomerase (Pgi - EC 5.3.1.9)}

The staining solution for detecting the enzyme phosphoglucose isomerase was modified from the following publications: Shaw and Prasad (1970), Allendorf et al. (1977) and Alfenas et al. (1991). Thus, $7 \mathrm{mg}$ PMS, $14 \mathrm{mg}$ MTT, $7 \mathrm{mg}$ NADP, $28 \mu \mathrm{L}$ G-6-PDH, $14 \mathrm{mg} \mathrm{MgCl}{ }_{2}$ and $28 \mathrm{mg}$ of D-fructose 6-phosphate disodium salt were dissolved in $70 \mathrm{~mL} 0.1 \mathrm{M}$ Tris-HCl buffer, $\mathrm{pH}$ 7.5. The gel slices were then placed in plastic trays, immersed in the above solution and later incubated in a laboratory oven at $37^{\circ} \mathrm{C}$ for approximately $1 \mathrm{~h}$ until the development of bands. The staining solution was then discarded and the gels, after being washed with distilled water, were fixed in a $10 \%$ glycerol solution.

\section{Superoxide dismutase (Sod - EC 1.15.1.1)}

For detecting the enzyme superoxide dismutase two solutions were prepared following the method described by Allendorf et al. (1977) with modifications. The first solution contained $17 \mathrm{mg}$ MTT and $5 \mathrm{mg}$ PMS dissolved in $25 \mathrm{~mL} 0.05 \mathrm{M}$ Tris- $\mathrm{HCl}$ buffer, $\mathrm{pH}$ 8.5. The second solution was prepared with agar ( $2 \%$ of the final staining solution) dissolved by 
heating up to the boiling point in $25 \mathrm{~mL}$ of the above Tris- $\mathrm{HCl}$ buffer and left to cool down to a temperature of approximately $50^{\circ} \mathrm{C}$. The two solutions were then mixed by stirring and the final solution was poured on the gel. Finally, the gel was incubated in the laboratory oven at $37^{\circ} \mathrm{C}$ under light for $30 \mathrm{~min}$ or until development of the achromatic bands.

\section{RESULTS}

Starch gel electrophoresis patterns of the enzymes Est, Ldh, Mdh, Pgm, Pgi, and Sod were determined for 60 skeletal muscle specimens, 27 from $S$. aequifasciatus and 33 from $S$. discus, which revealed electrophoretic bands of activity presumably controlled by 11 monomorphic loci (Table 1). The zymogram description for each enzyme examined is presented below.

\begin{tabular}{|c|c|c|}
\hline Locus and allele & $\begin{array}{l}\text { S. aequifasciatus } \\
\text { Manacapuru } \\
(\mathrm{N}=27)\end{array}$ & $\begin{array}{c}\text { S. discus } \\
\text { Novo Airão } \\
(\mathrm{N}=33)\end{array}$ \\
\hline Est- $1^{1}$ & 1.00 & 1.00 \\
\hline Est-2 ${ }^{1}$ & 1.00 & 1.00 \\
\hline Est- $3^{1}$ & 1.00 & 1.00 \\
\hline Ldh-1 $1^{1}$ & 1.00 & 1.00 \\
\hline Ldh-2 ${ }^{1}$ & 1.00 & 1.00 \\
\hline Mdh- $1^{1}$ & 1.00 & 1.00 \\
\hline Mdh- $2^{1}$ & 1.00 & 1.00 \\
\hline Pgi- $1^{1}$ & 1.00 & 1.00 \\
\hline Pgi-2 ${ }^{1}$ & 1.00 & 1.00 \\
\hline Pgm- $1^{1}$ & 1.00 & 1.00 \\
\hline Sod-1 ${ }^{1}$ & 1.00 & 1.00 \\
\hline
\end{tabular}

Est = esterase $; \mathrm{Ldh}=$ lactate dehydrogenase $; \mathrm{Mdh}=$ malate dehydrogenase $;$ Pgi = phosphoglucose isomerase $;$ Pgm $=$ phosphoglucomutase; Sod $=$ superoxide dismutase.

\section{Esterase}

The enzyme esterase showed three major activity bands with an isozyme pattern presumably encoded by the monomorphic loci Est-1, Est-2 and Est-3, which were fixed for the same alleles Est- $1^{1}$, Est- $2^{1}$ and Est- $3^{1}$ in all specimens of discus and are, therefore, not useful as taxonomic genetic markers for the two species examined (Table 1, Figure 3A). The Est-1 and Est-2 loci were visualized near the anodic region of the gel, whereas the Est-3 locus was seen near the cathodic region. Several diffuse bands of low staining intensity were visualized in the intermediate region of the gel located between the loci Est-2 and Est-3. As these diffuse bands were not clearly visualized on the gels to be genetically interpreted, they may be assumed to be secondary isoenzymes, which usually appear in zymograms probably due to electrophoretic artifacts produced by post-translational modifications in the polypeptide chains, as explained by Harris and Hopkinson (1978). Nevertheless, the presence of these secondary isoenzymes in the esterase zymogram did not lead us to a misidentification of these enzyme loci. 

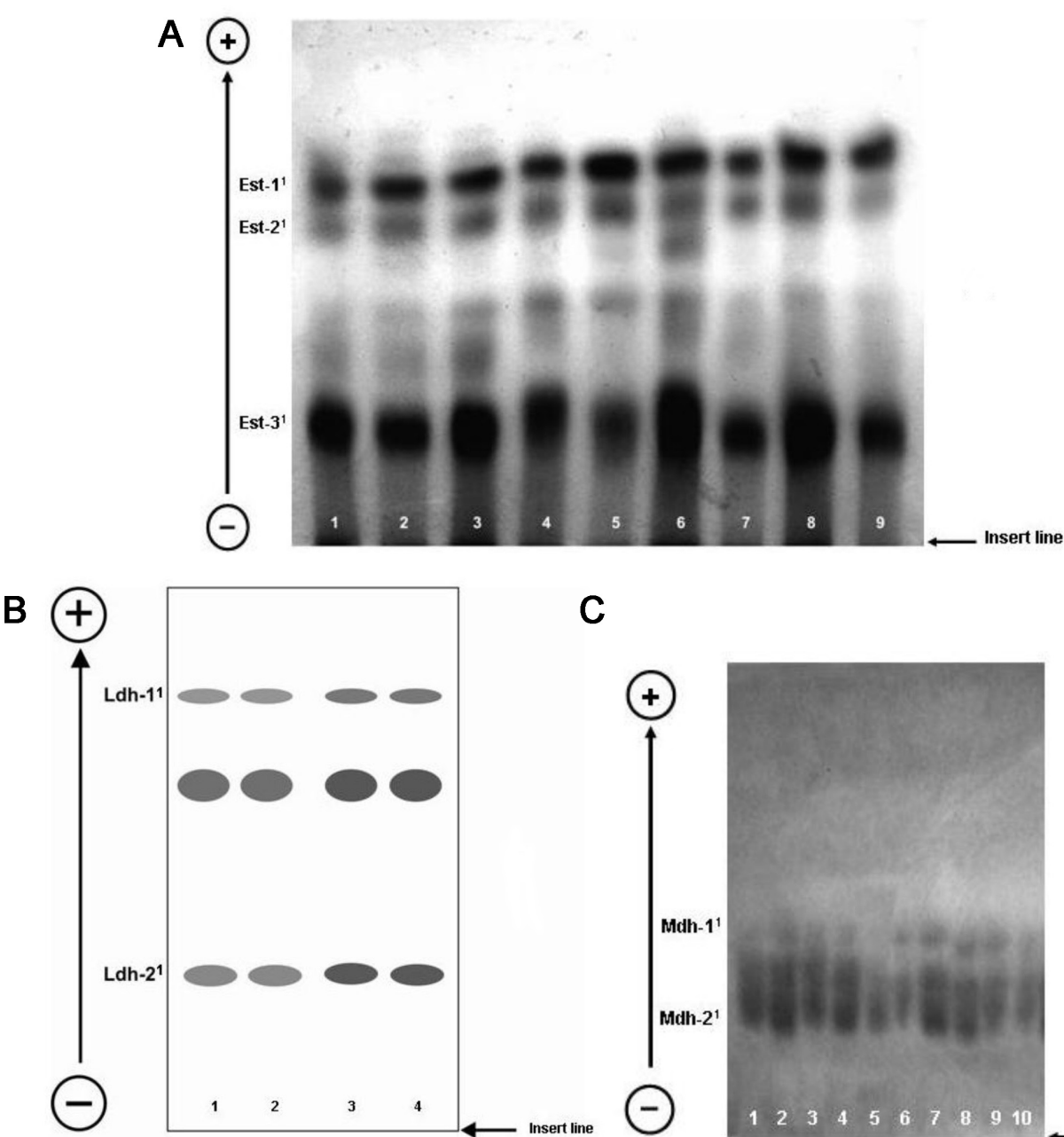

C

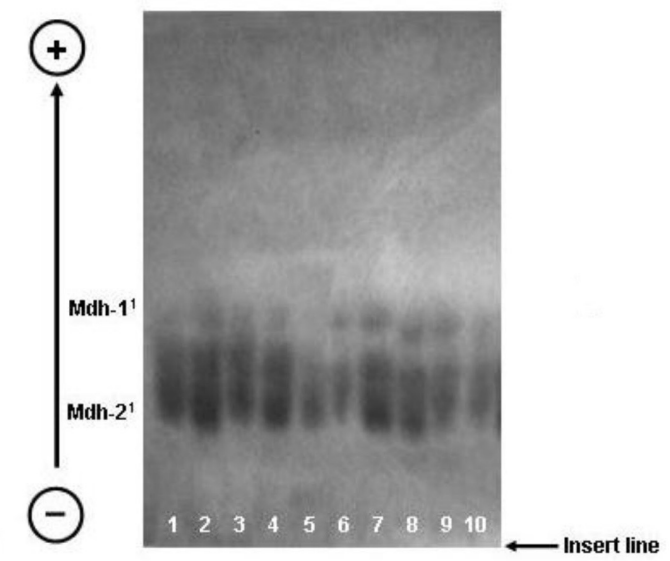

Figure 3. A. Zymogram of esterase showing the monomorphic loci fixed for the same alleles Est- $1^{1}$, Est- $2^{1}$ and Est- $3^{1}$ (Symphysodon discus: lanes 1 to 3, 7 to 9; S. aequifasciatus: lanes 4 to 6). B. Schematic representation of the lactate dehydrogenase zymogram revealing the monomorphic loci fixed for the same alleles Ldh- $1^{1}$ and Ldh-2 ${ }^{1}$ (S. aequifasciatus: lanes 1 and 2; S. discus: lanes 3 and 4). C. Zymogram of malate dehydrogenase showing the monomorphic loci fixed for the same alleles Mdh- $1^{1}$ and Mdh-2 ${ }^{1}$ (S. discus: lanes 1 to $5 ; S$. aequifasciatus: lanes 6 to 10$)$.

\section{Lactate dehydrogenase}

Two major electrophoretic bands of lacatate dehydrogenase activity were detected with an isoenzyme pattern presumably encoded by the monomorphic loci Ldh-1 and Ldh2 , which were fixed for the same alleles Ldh- $1^{1}$ and Ldh- $2^{1}$ shared by all discus specimens 
and are, therefore, not useful as taxonomic genetic markers for the two species in question (Table 1, Figure 3B). The Ldh-1 locus was revealed near the anodic region of the gel while the Ldh-2 was seen near the cathode region. Two minor staining bands showing electrophoretic migrations just in front of the Ldh-2 locus were only observed in $S$. aequifasciatus, which were not genetically interpreted, as these bands are presumably considered to be secondary isoenzymes (see Harris and Hopkinson, 1978). The presence of these bands in the lactate dehydrogenase zymogram does not prevent correct identification of these enzyme loci. One band of higher staining intensity, which appeared between the loci Ldh-1 and Ldh-2 located on the gel just before the Ldh-1 locus, could be one of the expected heterotetramers usually visualized in lactate dehydrogenase zymograms of nearly all vertebrate species, including fishes. This enzyme shows a tetrameric molecular structure, which in many cases of $A$ and $B$ polypeptide subunits (monomers) can combine to produce homotetramers $\left(\mathrm{A}_{4}\right.$ and $\left.\mathrm{B}_{4}\right)$ and three heterotetramers $\left(\mathrm{A}_{3} \mathrm{~B}_{1}, \mathrm{~A}_{2} \mathrm{~B}_{2}, \mathrm{~A}_{1} \mathrm{~B}_{3}\right)$ (Markert and Faulhaber, 1965; Ferguson, 1980).

\section{Malate dehydrogenase}

Two major electrophoretic bands of malate dehydrogenase activity were observed on the gels, presumably as the products of the monomorphic loci Mdh-1 and Mdh-2, which were fixed for the same alleles Mdh- $1^{1}$ and Mdh- $2^{1}$ shared by all discus specimens and are, therefore, not useful for diagnosing the species of discus tested (Table 1, Figure 3C). The Mdh-1 and Mdh-2 loci were scored in the intermediate and cathodic regions of the gels, respectively. It was always noticed when the muscle samples were homogenized in distilled water in order to obtain the protein supernatant, that there were two to three secondary bands distributed between the loci Mdh-1, Mdh-2 and the heterodimer, unlike when the muscle homogenates were prepared in $0.1 \mathrm{M}$ Tris- $\mathrm{HCl}$ buffer, $\mathrm{pH}$ 7.1, containing $1 \% \beta$-mercaptoethanol. Mdh often shows a series of bands of different electrophoretic mobilities, which appear to be due to different stable configurations and not caused by any difference in its primary structure (Ferguson, 1980). However, as the Mdh zymogram typing in the present study was based on protein supernatants prepared with $\beta$-mercaptoethanol as reducing agent, the appearance of the above mentioned secondary bands did not affect the identification of these enzyme loci.

\section{Phosphoglucomutase}

The phosphoglucomutase enzyme was represented by an invariant electrophoretic zone of activity, in the proximity of the intermediate region of the gel, with a three-band pattern presumably encoded by the monomorphic locus Pgm-1, which was fixed for the same allele Pgm- $1^{1}$ in all specimens examined and is, therefore, not useful as taxonomic genetic marker for the two species tested (Table 1, Figure 4A).

\section{Phosphoglucose isomerase}

For the enzyme phosphoglucose isomerase, two major and invariant electrophoretic bands of activity were detected from the vicinity of the intermediate region to the most ca- 
thodal region of the gel, presumably encoded by the monophorphic loci Pgi-1 and Pgi-2, respectively, which were fixed for the same alleles Pgi- $1^{1}$ and Pgi- $2^{1}$ in all specimens of discus and are, therefore, not useful as taxonomic genetic markers for the two species examined (Table 1, Figure 4B).

A

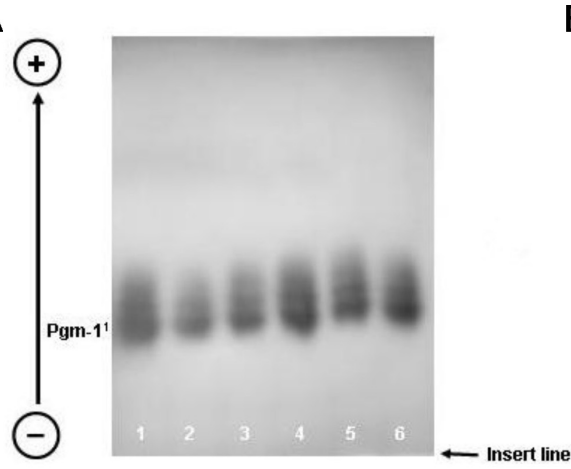

B

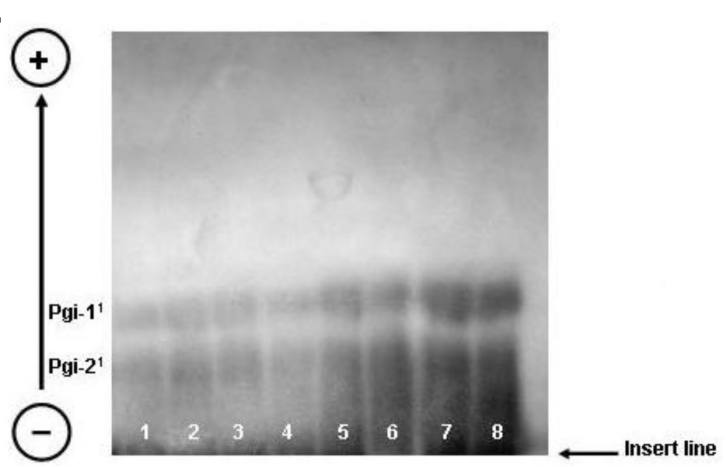

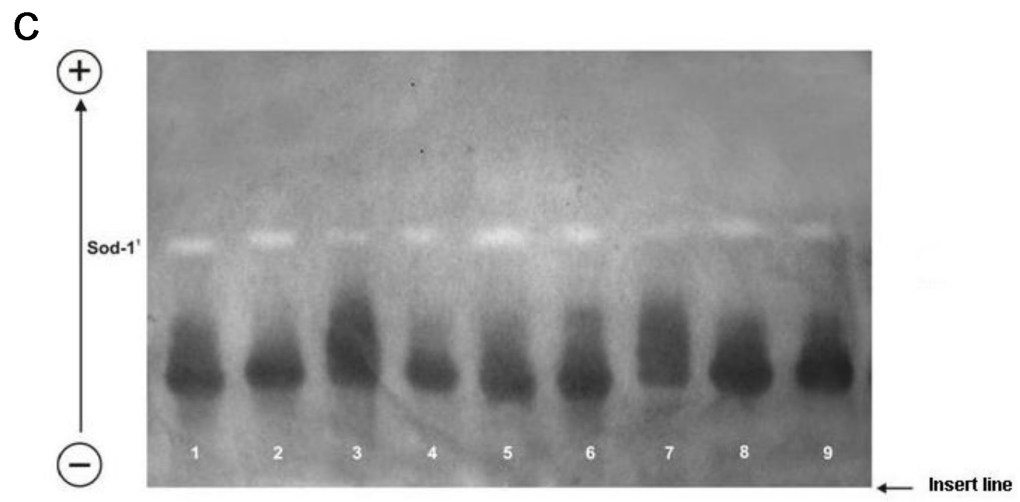

Figure 4. A. Zymogram of phosphoglucomutase showing the monomorphic locus fixed for the same allele Pgm- $1^{1}$ (Symphysodon discus: lanes 1 to 3; S. aequifasciatus: lanes 4 to 6). B. Zymogram of phosphoglucose isomerase revealing the monomorphic loci fixed for the same alleles Pgi- $1^{1}$ and Pgi- $2^{1}$ (S. discus: lanes 1 to 4; S. aequifasciatus: lanes 5 to 8;). C. Zymogram of superoxide dismutase showing the monomorphic locus fixed for the same allele Sod-1 ${ }^{1}$ (S. discus: lanes 1, 2, 4, 5, 6, 8, and 9; S. aequifasciatus: lanes 3 and 7).

\section{Superoxide dismutase}

In superoxide dismutase, one electrophoretic band of activity was detected in the intermediate region of the gel, presumably reflecting the expression of the monomorphic locus Sod-1, which was fixed for the same allele Sod- $1^{1}$ in all fish specimens. Thus, it is not applicable in the same manner as noted for the previously described enzymes, as a diagnostic taxonomic marker for the two species of discus surveyed (Table 1, Figure 4C). 


\section{DISCUSSION}

\section{Potential applications of isoenzyme markers in taxonomic and population studies}

The effective application of isoenzymes as molecular genetic markers for resolving taxonomic disputes (overlapping of meristic and morphometric characters and variation in color patterns) in fish, or in the most diverse types of organisms, has been unquestionable, especially, when comparison between species isoenzyme patterns shows diagnostic loci (characterized by presenting species-specific fixed alleles). It is important to emphasize that normally just a certain variable percentage of diagnostic loci has been detected and has significantly contributed to the correct identification of different closely related taxonomic units, as already reported in plants (Angelov, 2006), parasites (Šnabel et al., 2004), insects (Scarpassa and Hamada, 2003), crustaceans (Gusmão et al., 2006), mollusks (Durand et al., 1998; Gallardo et al., 2003), fishes (Smith and Robertson, 1981; Whitehead et al., 1985; Arculeo et al., 1999; Renesto et al., 2000; Fisch-Muller et al., 2001; Pujolar and Pla, 2002), amphibians (Kenneth and Richard, 2001), and mammals (Smit and Van der Bank, 2001), among others.

The effectiveness of using isoenzymes as molecular genetic markers applied as diagnostic tools for identifying and delimiting fish stocks, or any other kind of living stocks, depends essentially on the detection of polymorphism, which in this case, examination for genetic heterogeneity among population samples can be carried out by using statistical analysis such as a $\chi^{2}$ contingency table or exact probability test (Jamieson and Turner, 1978; Jamieson and Birley, 1989; Ferguson et al., 1995). Polymorphic isoenzyme loci have been successfully used to differentiate populations of several fish species (Chaplin et al., 1998; Poulet et al., 2004; Verspoor et al., 2005; Hovgaard et al., 2006).

Even keeping in mind the recent divergence between S. aequifasciatus and S. discus in the lower Amazon (Ready et al., 2006), the failure of the present study to detect diagnostic loci, which could effectively be used for distinguishing these two species and polymorphic loci as well as for possible identification and delimitation of their stocks, does not rule out their possible existence in other enzyme systems.

\section{Chromosome and molecular markers for determination of taxonomic status of discus fish}

Both chromosome and molecular markers have been applied as auxiliary tools for solving taxonomic problems of the discus.

Cytogenetic analyses revealed that the genus Symphysodon shows a diploid number of chromosomes equal to 60 , but with a pronounced inter- and intra-populational variety of karyotypes in terms of chromosome morphology (Mesquita et al., 2002; Gross, 2006), with 10 different karyotype formulae described for S. aequifasciatus and 6 for S. discus (Gross, 2006). However, the main difference between these two species was revealed by means of meiotic analyses (during the period of prophase I) in which $S$. aequifasciatus showed a chromosome chain formed by 20 elements plus 20 bivalents, whereas $S$. discus showed its chromosomes organized in 30 bivalents (Gross, 2006).

Random amplified polymorphic DNA markers have already been applied by Koh et al. (1999) for analyzing genetic relationships between wild forms and cultivated varieties of 
discus (Symphysodon spp). These authors pointed out that although the wild forms of S. discus and $\mathrm{S}$. aequifasciata (= S. aequifasciatus) appeared to be genetically distinct, the problem about the exact taxonomic status of these species needs to be resolved. Recently, Ready et al. (2006) examined Symphysodon samples collected from several areas of the Amazon basin, and, surprisingly, they did not detect differences at the mtDNA level between the two historically described species, S. aequifasciatus and S. discus. When these authors combined color pattern, morphology and mtDNA haplotypes, they could reveal the existence of a third discus species named S. tarzoo, which is distinguished by the diagnostic phenotype character of red spots on the sides of the body. Ready et al. (2006), who showed evidence of a phylogeographic barrier in the genus Symphysodon, demonstrated that the S. tarzoo specimens analyzed appeared mainly in the areas upstream of the Purus arch (western Amazon), and S. aequifasciatus specimens from locations downstream of this arch. However, most recently, in contrast to findings of Ready et al. (2006), Bleher et al. (2007), based on DNA sequences of partial mitochondrial control regions of Symphysodon specimens collected along the central and lower Amazon, revealed three genetically distinct clades, S. aequifasciatus, S. haraldi and S. discus. Moreover, Bleher et al. (2007) presented a series of arguments against the name S. tarzoo given by Ready et al. (2006) to the green discus, and referred to it as S. aequifasciatus.

Considering that the taxonomic status of the Amazon wild discus still remains complex, polemic, intriguing, and at the same time very attractive, we believe that the information generated by molecular markers (proteins, isoenzymes, mtDNA and DNA, microsatellites) and chromosome markers complemented with meristic-morphometric data should significantly contribute to a better understanding of this matter, and additionally provide basic support for the present fishery management and future conservation. In this context, the application of proteins and/or isoenzymes as auxiliary molecular tools must pursue a continued search for discovering: 1) diagnostic loci for identifying the species and 2) polymorphic loci showing Mendelian segregation of co-dominant alleles and significant genetic heterogeneity among population samples, in an attempt to identify and delimit natural stocks of discus fish in the Amazon region.

\section{ACKNOWLEDGMENTS}

The authors are thankful to the National Research Institute of Amazonia (INPA), which supported the present study through the Institutional Project Programme (PPI 1-0505), Dr. Eliana Feldberg and Maria Claudia Gross for sharing useful information and discussion on the current taxonomic status of discus fish, Mr. Manoel Santana and local fishermen for collecting fish samples, Mr. Felipe França de Moraes for drawings and Mr. Herbert Allan Iwata Pollachini for figure illustrations, Mr. Arnaldo Lima and his wife who provided physical space for taking fish tissue samples, and Mr. George Nakamura for revising the English.

\section{REFERENCES}

Alfenas AC, Peters I, Brune W and Passador GC (1991). Eletroforese de Proteínas e Isoenzimas de Fungos e Essências Florestais. UFV, Imprensa Universitária, Viçosa.

Allendorf FW, Mitchell N, Ryman N and Stahl G (1977). Isozyme loci in brown trout (Salmo trutta L.): detection and interpretation from population data. Hereditas 86: 179-190.

Angelov GB (2006). Isoenzyme diversity and affinity between Dactylis glomerata and Puccinellia maritima (Poaceae).

Genetics and Molecular Research 7 (3): 791-805 (2008)

CFUNPEC-RP www.funpecrp.com.br 
Proc. Estonian Acad. Sci. Biol. Ecol. 55: 267-279.

Arculeo M, Mauro A, Lo Brutto S, Mirto S, et al. (1999). Biochemical genetic differentiation between Pomatoschistus marmoratus and P. tortonesei. J. Fish Biol. 54: 190-195.

Axelrod HR (2001). Discovery of the Cardinal Tetra and Beyond. In: Conservation and Management of Ornamental Fish Resources of the Rio Negro Basin, Amazonia, Brazil (Chao NL, Prang G, Sonneschien L and Tlusty M, eds.). Editora da Universidade do Amazonas, Manaus, 17-25.

Axelrod HR, Burguess WE, Emmens CW, Pronek N, et al. (1995). Dr. Axelrod Mini-Atlas of Freshwater Aquarium Fishes - Mini Edition. T.F.H. Publications Inc., Neptune City.

Bleher H, Stölting KN, Salzburger W and Meyer A (2007). Revision of the genus Symphysodon Heckel, 1840 (Teleostei: Perciformes: Cichlidae) based on molecular and morphological characters. Aqua Int. J. Ichthyol. 12: 133-174.

Brune W, Alfenas AC and Junghans TG (1998). Identificações Específicas de Enzimas em Géis. In: Eletroforese de Isoenzimas e Proteínas Afins: Fundamentos e Aplicações em Plantas e Microorganismos (Alfenas AC, ed.). Editora da Universidade Federal de Viçosa, Viçosa, 201-328.

Carvalho GR and Hauser L (1994). Molecular genetics and the stock concept in fisheries. Rev. Fish Biol. Fish. 4: 326-350.

Chao NL (2001). The Fishery, Diversity, and Conservation of Ornamental Fishes in the Rio Negro Basin, Brazil - A Review of Project Piaba (1989-1999). In: Conservation and Management of Ornamental Fish Resources of the Rio Negro Basin, Amazonia, Brazil - Project Piaba (Chao NL, Petry P, Prang G, Sonneschien L, et al., eds.). Editora da Universidade do Amazonas, Manaus, 161-204.

Chao NL and Prang G (2002). Decade of Project Piaba: reflections and prospects. OFI J. (Ornamental Fish International) 39: 24-27.

Chaplin JA, Baudains GA, Gill HS, McCulloch R, et al. (1998). Are assemblages of black bream (Acanthopagrus butcheri) in different estuaries genetically distinct? Int. J. Salt Lake Res. 6: 303-321.

Durand P, Yong M, Perera G, Ducreux A, et al. (1998). Genetic evidence of two species in the Biomphalaria havanensis complex (Gastropoda - Planorbidae) from Cuba. Acta Trop. 71: 179-188.

Ferguson A (1980). Biochemical Systematics and Evolution. Blackie, Glasgow and London.

Ferguson A, Taggart JB, Prodohl PA, McMeel O, et al. (1995). The application of molecular markers to the study and conservation of fish populations, with special reference to Salmo. J. Fish Biol. 47: 103-126.

Fisch-Muller S, Mazzoni R and Weber C (2001). Genetic and morphological evidences for two new sibling species of Ancistrus (Siluriformes: Loricariidae) in upper rio Tocantins drainage, Brazil. Ichthyol. Explor. Freshwat. 12: 289-304.

Gallardo MH, González C, Mena C and Lomovasky B (2003). Allozymic variation in the clam genus Eurhomalea (Bivalvia: Veneriidae) along southern South American coast. Rev. Chil. Hist. Nat. 76: 501-507.

Gerstner CL, Ortega H, Sanchez H and Graham DL (2006). Effects of the freshwater aquarium trade on wild fish populations in differentially-fished areas of the Peruvian Amazon. J. Fish Biol. 68: 862-875.

Gross MC (2006). Comportamento cromossômico meiótico nas células gonadais de machos de acará-disco, Symphysodon discus e S. aequifasciatus (Perciformes, Cichlidae). Master's thesis, Instituto Nacional de Pesquisas da Amazônia, Manaus.

Gusmão J, Lazoski C, Monteiro FA and Solé-Cava AM (2006). Cryptic species and population structuring of the Atlantic and Pacific seabob shrimp species, Xiphopenaeus kroyeri (Heller 1862) and X. riveti (Bouvier 1907). Mar. Biol. 149: 491-502.

Guyomard R (1993). Methods to Describe Fish Stocks. In: Symposium on Genetic Conservation of Salmonid Fishes (Cloude JG and Thorgaard TH, eds.). Plenum Press, New York, 1-22.

Harris H and Hopkinson DA (1978). Handbook of Enzyme Electrophoresis in Human Genetics. American Elsevier, New York.

Hovgaard K, Skaala O and Nævdal G (2006). Genetic differentiation among sea trout, Salmo trutta L., populations from western Norway. J. Appl. Ichthyol. 22: 57-61.

Jamieson A and Turner RJ (1978). The Extended Series of Tf Alleles in Atlantic cod, Gadus morhua. In: Marine Organisms (Battaglia B and Beardmore JA, eds.). Plenum Publishing Corporation, New York, 699-729.

Jamieson A and Smith PJ (1987). Atlantic mackerel (Scomber scombrus L.) stocks and genes: A review. ICES J. Mar. Sci. 44: 66-72.

Jamieson A and Birley AJ (1989). The distribution of transferrin alleles in haddock stocks. J. Cons. Int. Explor. Mer. 45: 248-262.

Kenneth HK and Richard RM (2001). Genetic variation across a contact zone between montane and lowland forms of the two-lined Salamander (Eurycea bislineata) species complex: a test of species limits. Copeia 1: 25-34.

Koh TL, Khoo G, Fan LQ and Phang VPE (1999). Genetic diversity among wild forms and cultivated varieties of Discus (Symphysodon spp.) as revealed by random amplified polymorphic DNA (RAPD) fingerprinting. 
Aquaculture 173: 485-497.

Kullander SO (1996). Eine Weitere Übersicht der Diskusfische, Gattung Symphysodon Heckel. Diskus. DATZ, Sonderheft.

Kullander SO (1998). A Phylogeny and Classification of the South American Cichlidae (Teleostei, Perciformes). In: Phylogeny and Classification of Neotropical Fishes (Malabarba LR, Reis RE, Vari RP, Lucena ZM, et al., eds.). EDUPUCRS, Porto Alegre, 461-498.

Kullander SO (2003). Family Cichlidae. In: Check List of the Freshwater Fishes of South and Central America (Reis RE, Kullander SO and Ferraris CJ Jr, eds.). EDIPUCRS, Porto Alegre, 605-654.

Markert CL and Faulhaber I (1965). Lactate dehydrogenase isozyme patterns of fish. J. Exp. Zool. 159: 319-332.

Mazeroll AI and Weiss M (1995). The State of Confusion in Discus Taxonomy. In: The Cichlids Yearbook (Konings A, ed.). Vol. 5. Cichlid Press, St. Leon-Rot, 77-83.

Mesquita DR, Porto JIR and Feldberg E (2002). Análise da variabilidade cromossômica do peixe ornamental "acará disco" (Symphysodon discus Heckel, 1840; S. aequifasciatus Pellegrin, 1904; Cichlidae) do Amazonas. Master's thesis, UFSC/UFA, Manaus.

Micales JA, Alfenas AC and Bonde MR (1998). Izoenzimas na Taxonomia e na Genética de Fungos. In: Eletroforese de Isoenzimas eProteínas Afins. Fundamentos e Aplicações em Plantas e Microrganismos (Alfenas AC, ed.). Universidade Federal de Viçosa, Viçosa, 477-502.

Mills D (1998). Peixes de Aquário. Ediouro, Rio de Janeiro.

Nomenclature Committee of the International Union of Biochemistry and Molecular Biology (NC-IUBMB) (2006). Available at http://www.chem.qmul.ac.uk/iubmb/enzyme. Accessed November 14, 2006.

Poulet N, Berrebi P, Crivelli AJ, Lek S, et al. (2004). Genetic and morphometric variations in the pikeperch (Sander lucioperca L.) of a fragmented delta. Arch. Hydrobiol. 159: 531-554.

Pujolar JM and Pla C (2002). Occurrence of dolphinfish (Coryphaena hippurus) and pompano dolphinfish (Coryphaena equiselis) in the Canary Islands revealed by genetic analysis. N. Z. J. Mar. Freshwat. Res. 36: 339-343.

Ready JS, Ferreira EJG and Kullander SO (2006). Discus fishes: mitochondrial DNA evidence for a phylogeographic barrier in the Amazonian genus Symphysodon (Teleostei: Cichlidae). J. Fish Biol. 69: 200-211.

Renesto E, Zawadzki CH and Revaldaves E (2000). Genetic evidence for two species of the genus Pimelodus Lacépède, 1803 (Siluriformes, Pimelodidae) in the Iguaçu River (Brazil). Genet. Mol. Biol. 23: 809-813.

Ridgway GJ, Sherburne SW and Lewis SD (1970). Polymorphism in the esterases of Atlantic herring. Trans. Am. Fish. Soc. 99: 147-151.

Scarpassa VM and Hamada N (2003). Isozyme variation in four species of the Simulium perflavum species group (Diptera: Simuliidae) from the Brazilian Amazon. Genet. Mol. Biol. 26: 39-46.

Shaw CR and Prasar R (1970). Starch gel electrophoresis of enzymes - a compilation of recipes. Biochem. Genet. 4: 297 320.

Silva T and Kotlar B (1980). Discus. T.F.H. Publications Inc., Neptune City.

Smit AA and Van der Bank HF (2001). Isozyme and allozyme markers distinguishing two morphologically similar, medically important Mastomys species (Rodentia: Muridae). BMC Genet. 2: 15.

Smith PJ and Robertson DA (1981). Genetic evidence for two species of sprat (Sprattus) in New Zealand waters. Mar. Biol. 62: 227-233.

Smith PJ, Patchel GJ and Benson PG (1981a). Genetic tags in the New Zealand hoki, Macruronus novaezelandiae. Anim. Blood Groups Biochem. 12: 37-45.

Smith PJ, Roberts PE and Hurst RJ (1981b). Evidence for two species of arrow squid in the New Zealand fishery. N. Z. J. Mar. Freshwat. Res. 15: 247-253.

Snabel V, Hanzelova V, Scholz T, Gerdeaux D, et al. (2004). Allozyme analysis of genetic variation and polymorphism in Eubothrium salvelini and E. crassum (Cestoda: Pseudophyllidea) from alpine lakes. Parasitol. Res. 93: 290-295.

Utter FM (1991). Biochemical genetics and fishery management: a historical perspective. J. Fish Biol. 39: 1-21.

Verspoor E, Beardmore JA, Consuegra S, Garcia de Leaniz C, et al. (2005). Population structure in the Atlantic salmon: insights from 40 years of research into genetic protein variation. J. Fish Biol. 67: 3-54.

Whitehead PJP, Smith PJ and Robertson DA (1985). The two species of sprat in New Zealand waters (Sprattus antipodum and S. muelleri). N. Z. J. Mar. Freshwat. Res. 19: 261-271. 